\title{
Swedish Imaginings, Investments and Local Photography in Jerusalem, 1925-1939
}

\author{
Inger Marie Okkenhaug
}

In the fall of 1925, Lord Herbert Plumer (1857-1932), the newly appointed High Commissioner to Palestine, made an official visit to a small school for Arab children in Jerusalem, run by the Protestant organisation the Swedish Jerusalem Society (sJs). ${ }^{1}$ Also present was Palestine's Director of Education, Humphrey Bowman (1879-1965). The presence of these British dignitaries made the visit a major event in the history of the school, narrated in text and photographs and published for supporters in Sweden and North America. While the visit ended with tea and conversation in the teachers' comfortable office, a photograph of the meeting shows a formal setting with two women and four men standing in the doorway under a British flag, reminding us of the political realities in Palestine under British Mandate rule. To the left in the photograph stands the qawās - the Consular Guard - wearing the official Ottoman qawās uniform, hinting at the Middle East context. Next to the qawās we see the Swedish Consul in Jerusalem and member of the American Colony, Hol Lars (Lewis) Larsson (1881-1958). To Larsson's right stands High Commissioner Plumer, while Bowman is seen to the right of the picture. In the centre of the photographs, staring at the lens, is Swedish headmistress Signe Ekblad's tall and commanding figure, demanding our attention. ${ }^{2}$ The school's Palestinian teachers, Warda Abūdiyya, N. Ḥalabī, Ḥannā 'Abla, Bīdyā Ḥarāmī and Hīlīnā Kāssissiyya were also present at the official visit. However, in this photograph, taken by a photographer from the American Colony's Photo Department, it

1 SvenskaJerusalemsföreningen. I would like to thank Sary Zananiri, Karène Sanchez Summerer, Rachel Lev, Issam Nassar, Åsmund Svendsen and anonymous reviewers for insightful comments to various versions of this chapter. I would also like to thank Åsa Henningsson and other staff at the Uppsala University Library for invaluable help and assistance with the sJs-photo collection.

2 Comment by Issam Nassar at conference the "Imaging and Imagining Palestine", Leiden, October 16th 2019. These images of the Swedish school are all from the sjs collection held at the Uppsala University Library. They were printed in the sJs publication Svenska Jerusalemsföreningens Tidsskrift, and in Märta Lindqvist's travel book Palestinska dagar (“Palestinian Days") (Stockholm: Skoglund Bokförlag, 1931). 
is the British Mandate system that is visualised, to the exclusion of the Arab teachers.

During the interwar period the Swedish institution received state funding in a manner similar to other private schools and was part of the British Mandate's educational system. From the early 1920 s the school was headed by Signe Ekblad (1894-1952), who had come to Jerusalem as a young woman in 1922. ${ }^{3}$ Even so, the school's history went back to Ottoman rule and was established by the sJs in 1902. ${ }^{4}$ This organisation was founded in 1900 by members of the Swedish elite, and had strong connections to the Swedish state church and royal family, with King Oscar II as its 'high protector.' be modelled upon the German Jerusalemsverein. In a similar manner to the German organisation, sjs focused on welfare and humanitarian work that included a hospital in Bethlehem, (operating from 1903 to 1925), in addition to the school in Jerusalem. ${ }^{6}$ The organisation aimed at representing the Swedish nation in Palestine in the same manner as the Great Powers, France, Great Britain, Russia and Germany were represented through national Protestant and Catholic missions. In the Middle East missionaries faced major obstacles in their attempt to convert locals. ${ }^{7}$ As a consequence, organisations like the sJs increasingly shifted their focus from evangelisation to health and education. The sJs, active in Palestine from 1900 to 1948, when war forced the school to close down, transformed its vocation to non-proselytising welfare work among the local, Arab population. ${ }^{8}$

By the 1920s, Sweden had long ceased to be an expansionist colonial power, even so, in the inter war period, it is possible to locate Swedish expansionist

3 Lindquist, Palestinska dagar, 62.

4 Inger Marie Okkenhaug, "Scandinavian Missionaries in Palestine: The Swedish Jerusalem Society, Medical Mission and Education in Jerusalem and Bethlehem, 1900-1948," in Tracing the Jerusalem Code: Christian Cultures in Scandinavia, vol. 3., eds. Anna Bohlin and Ragnhild J. Zorgati (Berlin: De Gruyter Verlag, 2021). Sune Fahlgren, Mia Gröndahl, and Kjell Jonasson, eds., A Swede in Jerusalem. Signe Ekblad and the Swedish School, 1922-1948 (Bethlehem: Diyar Publishing and Swedish Jerusalem Society, 2012), 20.

5 During the Mandate period, King Oscar's granddaughter Countess Elsa Bernadotte af Wisborg, head of the Swedish YMCA, became an active supporter of the sjs school in Jerusalem. Gustaf Björk, Sverige i Jerusalem och Betlehem. Svenska Jerusalemsföreningen 1900-1948 (Uppsala: Svenska Jerusalemsföreningen, 2000), 50-51.

6 Björk, Sverige i Jerusalem och Betlehem, 14.

7 Conversion efforts were aimed mainly at the Jewish population, and largely failed.

8 See Inger Marie Okkenhaug, "Signe Ekblad and the Swedish School in Jerusalem, 19221948," Svensk Missionstidskrift 2 (2006): 147-162 and Inger Marie Okkenhaug, "Att avresa till Jerusalem som lärarinna: Signe Ekblad, jorsalsfarer, lærer og misjonær," in Religiøse reiser. Mellom gamle spor og nye mål, eds. Siv Ellen Kraft and Ingvild S. Gilhus (Oslo: Universitetsforlaget, 2007), 121-134. 


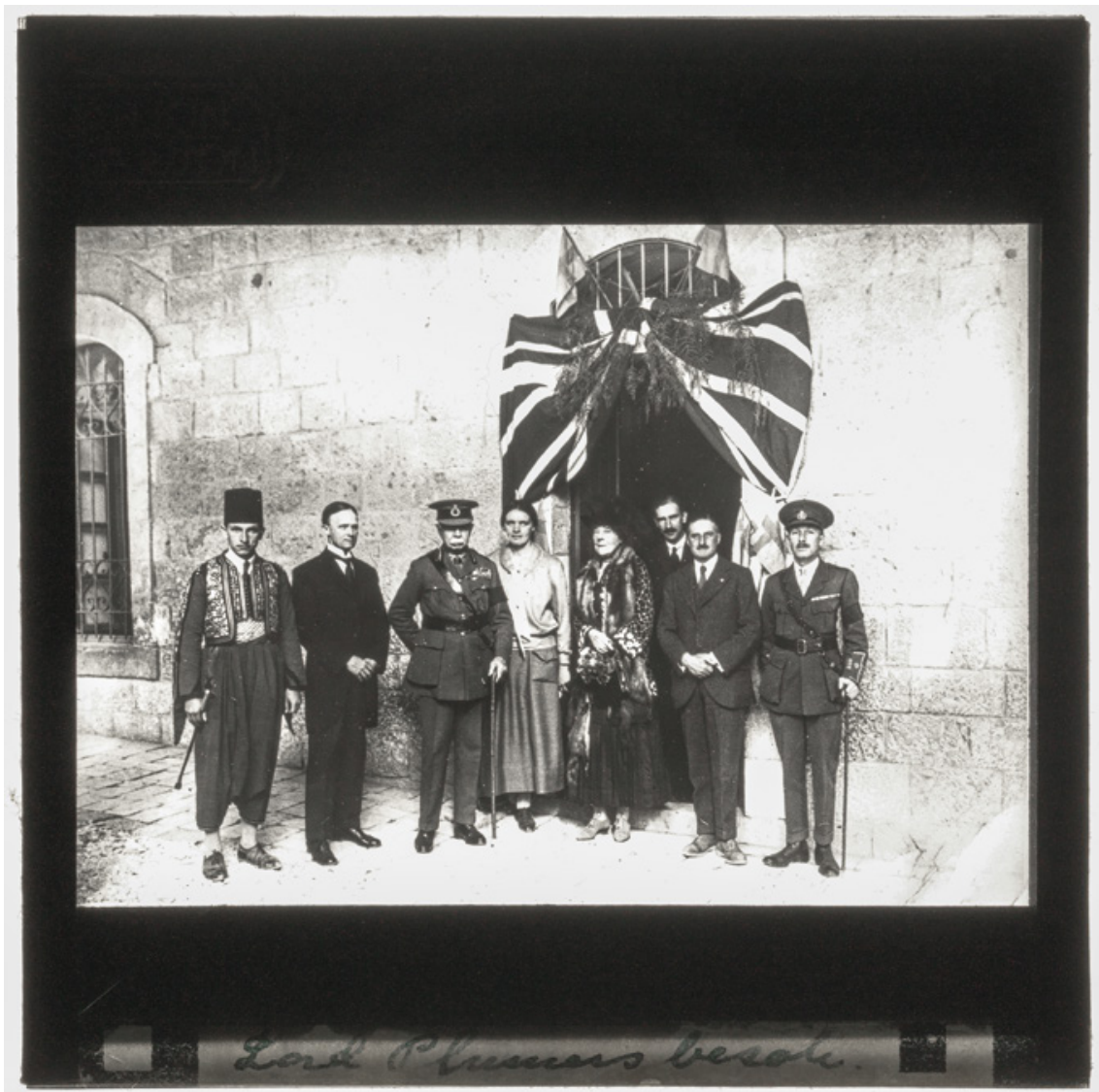

FIG URE 3.1 High Commissioner Herbert Plumer and Director of Education, Humphrey Bowman on an official visit to the Swedish School, 1925. American Colony Photo Department. From left: The Consular Guard, Hol Lars (Lewis) Larsson, Herbert Plumer, Signe Ekblad, unknown woman, unknown man, Humphrey Bowman, unknown man. Swedish Jerusalem Society's Collection, 270068 IMAGE COURTESY OF UPPSALA UNIVERSITY LIBRARY

ambitions in mission-based welfare projects in colonial (and Mandate) areas. ${ }^{9}$ In line with what some historians have labelled 'Nordic colonial thinking', ${ }^{10}$ a

9 See for example Seija Jalagin, Inger Marie Okkenhaug and Maria Småberg, "Introduction: Nordic Missions, gender and humanitarian practices: from evangelization to development," Scandinavian Journal of History 40, no. 3 (2015): 285-297.

10 Peter Forsgren, “Globalization as 'The White Man's Burden': Modernity and Colonialism in a Swedish Travelogue," Scandinavian Studies 91, nos. 1-2 (2019): 222-223. See also Johan Höglund and Linda Andersson Burnett, "Introduction: Nordic Colonialism and Scandinavian Studies," Scandinavian Studies 91, nos. 1-2 (2019): 1-12. 


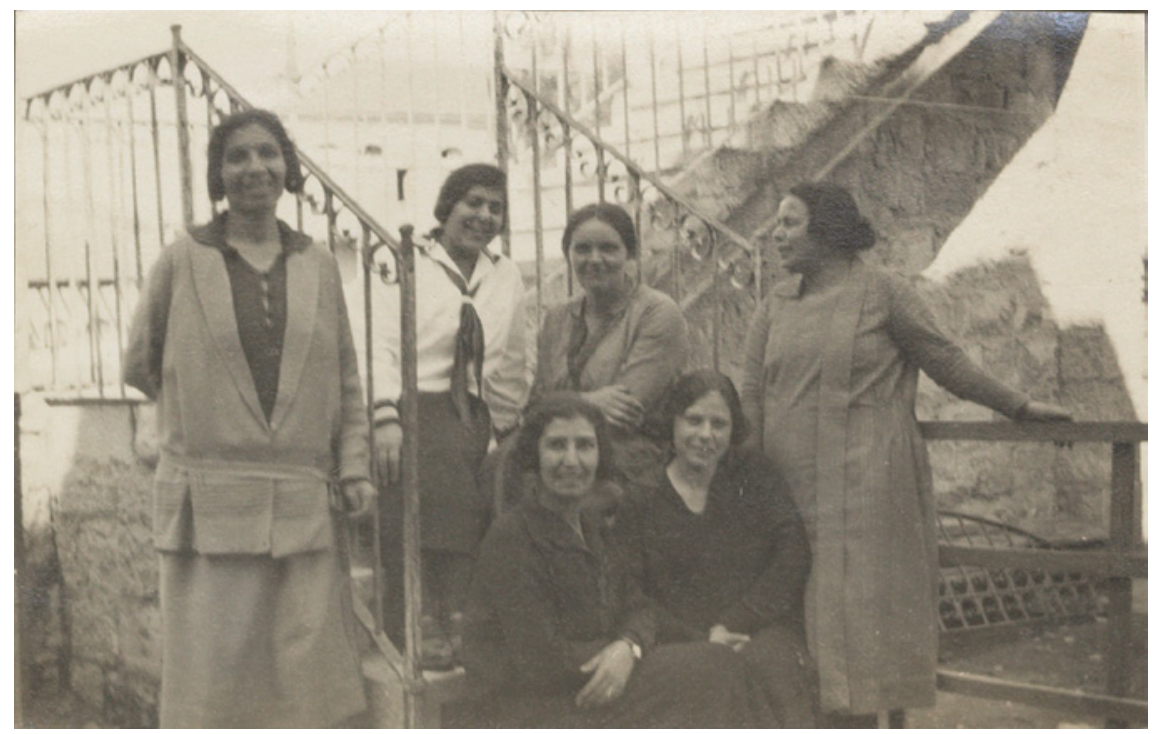

FIGURE 3.2 The Arab Teachers and headmistress Ekblad, the Swedish School during the Summer Term, 1926. Photographer unknown. Swedish Jerusalem Society's Collection, 396359

IMAGE COURTESY OF UPPSALA UNIVERSITY LIBRARY

humanitarian, Christian, Swedish presence in Palestine, helped boost Sweden's self-image as a modern, European nation. The export of Swedish modernity to Palestine was seen in the fact that the Swedish school was modelled on Swedish educational culture and to a large extent financed from Sweden. Even so, the school had a profound local connection to the Arab community.1 ${ }^{11}$ The staff consisted mainly of Christian Arab teachers and the pupils came from Arab families and, unlike most other mission schools, Arabic was the language of instruction. The connection to the local environment was strengthened with the purchase of land and a building in Jerusalem in June 1926. From renting a house outside the Damascus Gate, the Swedes now owned a property in Musrara, a prosperous Arab neighbourhood close to Prophet Street. The property included a stately villa which was reconstructed into a school for more

11 Björk, Sverige i Jerusalem och Betlehem, 28-29. The Swedish Jerusalem's Society (Svenska Jerusalemsföreningen), started out as a mission to the Jews, but due to Jewish hostility in Palestine the Swedish missionary agenda was very soon transformed into a cultural mission; in practical terms this meant education, health and relief work among the Arab population. The Swedish school opened in October 1902, providing a kindergarten and the first two years of primary school for girls. In 1909, Ottoman authorities officially recognised the school as the École de la Société de Jérusalem. 
than 100 pupils. In 1928 , the sjs added a new school building on their property, expanding the number of pupils to 25 o. Ten years later, in 1938, as a response to the humanitarian crisis caused by the war-like situation in Palestine, yet another building, a soup kitchen named the Green Hall, was added to the school premises.

This chapter focuses on photographs of the Swedish School, most of them published in the Swedish Jerusalem Society membership journal and the Swedish travel book Palestinska dagar (Palestinian Days) ${ }^{12}$ from c. 1925 to $1940 . .^{13}$

Some of these photographs were taken by Signe Ekblad and printed as illustrations to her articles in the sJs journal. While Ekblad was an amateur photographer, a number of the published photographs were taken by photographers from the American Colony Photo Department (ACPD). The photographic motifs of the Swedish School included official and private guests, pupils and staff, buildings, playground and wider surroundings, and the school's welfare work. The aim here is to examine the social history told in the sJs photographs. Importantly, there was a utilitarian aspect to the photographs: in a similar way to other Protestant missions, photographs were crucial to the funding campaigns. The daily operations of a mission's school or hospital depended on the generosity of 'friends' back home. The fact that the sjs operated in 'The Land of the Bible' where every Christian nation (of some size) longed for a presence was of course a great asset in convincing potential donors. The photographers and the audience, middle- and upper-middle class Swedish men and women with Protestant sympathies and a humanitarian consciousness, desired a Swedish presence in Palestine. This was motivated by religious faith and Swedish national patriotism, but manifested itself in humanitarian work. ${ }^{14}$ The Swedish people, wrote Ekblad in the sjs journal, not only had a duty to fulfil their gratefulness to the Holy Land. The people of Palestine expected the Swedes to act on this responsibility. ${ }^{15}$ After the closing of the sjs hospital in Bethlehem in 1925, the only way of living up to these expectations was to support the Swedish educational work in Jerusalem. In a similar manner to

\footnotetext{
12 Lindquist, Palestinska dagar.

13 These photographs are now kept at the sjs collection at Uppsala University Library. There is a total of seventeen albums in addition to loose photographs. There is no record of all photographs. Many of the images are found both in the albums and as loose photographs. See http://www.alvin-portal.org/alvin/view.jsf?pid=alvin-record\%3A92948\&dswid=1023. Personal communication, e-mail from Åsa Henningsson, November 5 th 2020.

14 See Okkenhaug, "Scandinavian Missionaries in Palestine."

15 Uppsala University Library, Svenska Jerusalemsföreningen's Archives Svenska Jerusalemsföreningens Tidsskrift 2 (1923): 97.
} 
the Swedish-American humanitarianism of the American Colony, as shown by Abigail Jacobson in this volume, photography played an integral part of Swedish welfare enterprise. I thus argue that the photographs, together with printed reports dealing with the Swedish humanitarian efforts in Palestine, visualised the imagined need for a Swedish presence in 'The Holy Land', but even more so the tangible results the Swedish engagement had in the country. Moreover, the article shows that while the photographs are visual documents of religious longing, they do not tend to dwell on ahistorical Biblical motifs. Instead, they reflect the thriving, intense process of modernity taking place in Palestine at the time, a process the Swedes wanted to take part in as a way of manifesting their claim to a national presence in Palestine. In addition, the photographs visualise the extent to which the Swedish enterprise was Palestinian; as mentioned earlier, the staff was mainly Arab and the school was part of a local Jerusalemite neighbourhood. Even so, the people in charge, the headmistress and board members were always Swedish. This external control is embodied in Ekblad's central presence in many of the photographs of the school.

This chapter is divided in three parts. The first part gives a background of the different people who were behind the photographs discussed here. The second part of the chapter focuses on photographs of the building process from 1927 to 1929. The third part focuses on the welfare and relief work of the Swedish institution, in particular the food distribution that took place from 1937 to 1939, during the Arab Revolt, thus offering an understanding of transnational welfare and local practice as imagined by the Swedish actors in Palestine.

\section{The Photographers}

Most noticeable here is the Colony's photo facility with its excellent laboratory where all photographic work imaginable is carried out. Even Baedeker (Palestine and Syria) says that fine pictures originate here, the best available in the Orient. ${ }^{16}$

This praise of the American Colony's Photo Department was voiced by Swedish Nobel Peace Prize Laureate Klas Pontus Arnoldson (1844-1916) who visited the American Colony in $1911{ }^{17}$ The American Evangelical Protestants who founded the pre-millennialist community in Jerusalem in 1881 were joined fifteen

\footnotetext{
16 Mia Gröndal, The Dream of Jerusalem. Lewis Larsson and the American Colony Photographers (Stockholm: Journal, 2005), 151.

17 Gröndal, The Dream of Jerusalem, 151.
} 
years later by a large group of Swedes and Swedish-Americans. The Colony's Photo department consisted of a collective of men with American, German, Palestinian, Indian and Swedish backgrounds. According to Rachel Lev, there were around fifteen photographers who operated the department between 1896 to $1934 .{ }^{18}$ One of them was Jerusalem born John D. Whiting (1882-1951), whose Diaries in Photos series is the topic of Rachel Lev's article in this volume. Whiting's peer and colleague Hol Lars (Lewis) Larsson became head of the Colony's Photo department. Larsson and a younger Swede, Eric Matson both photographed the Swedish school at various times. ${ }^{19}$ The high professional standard of the Photo department was widely acknowledged locally. In 1916, for example, the Red Crescent appointed Larsson as their head photographer in the region. ${ }^{20}$

The Swedish American Colony photographers were not Jerusalemites by birth. Hol Lars (Lewis) Larsson and Eric Matson had immigrated because their parents had joined a Swedish-American awakening movement. Even so, in a similar manner to Whiting and other photographers at the American Colony, these young Swedish men were fluent in Arabic and got to know Palestine and the region by extensive travels with their cameras. ${ }^{21}$ Nada Awad also underlines the local character of the American Colony's photographers: 'Unlike foreign photographers who came for short periods of time, the American Colony Photo department was established and run for more than thirty-seven years in Palestine by photographers who lived in the country, knew the culture; some of them were even born in Jerusalem and spoke Arabic. ${ }^{22}$ Larsson was one of these photographers who spoke both Arabic and English fluently. In 1921 he was to become Swedish vice consul in Palestine and full honorary consul in $1925 .{ }^{23}$ Larsson's double identity as local Jerusalemite and official Swedish representative was to be a major asset for the development of the Swedish School.

In the same manner as Larsson, Signe Ekblad would also develop a double identity as a Swede living and working in Jerusalem for most of her adult life. She was both a labour migrant and a religious agent seeking to fulfil her vocation. Before moving to Jerusalem, Ekblad had trained and worked as a teacher in Sweden. Later in life, after several years in Palestine, she received an MA in Semitic languages at Uppsala University. Her religious calling to become a

\footnotetext{
18 Rachel Lev, comment on the draft.

19 Gröndal, The Dream of Jerusalem, 161.

20 Gröndal, The Dream of Jerusalem, 216.

21 See Edith Larsson, Dalafolket I Heligt Land (Stockholm: Natur och Kultur, 1957).

22 Nada Awad, "Waiting for the Second Coming: The New Photographic Collection of the American Colony Archives," Jerusalem Quarterly 61 (2015): 101-112, 105.

23 Gröndal, The Dream of Jerusalem, 242.
} 
teacher in Jerusalem was inspired by her time working for the Swedish settlement movement's work among poor industrial workers in the settlement of Birkagården in Stockholm. ${ }^{24}$ Birkagården, was inspired by the work of the British settlement movement in the slums of inner London. It had its supporters among the radical, Christian, cultural and intellectual elite in Sweden. Social Christianity, with an emphasis on reconciliation between the classes and self-help rather than charity, were the central points of this movement. ${ }^{25}$ This ideology, which contributed significantly to the establishment of the welfare state, influenced Ekblad's understanding of her mission in Palestine. ${ }^{26}$ The idea of Christian faith, expressed as practical welfare work, was something Ekblad had in common with Larsson and other members of the American Colony.

Before World War I, connections were not close between the Swedish members of the American Colony and the sJs, as the confessional differences were too considerable. ${ }^{27}$ The high church, elite profile of the sjs (as represented by the Swedish medical staff in Bethlehem $)^{28}$ and the rural and low church background of the Swedish members of the American Colony might also explain the distant relationship between the Swedes in Palestine. ${ }^{29}$ After the First World War, however, relations between the Colony and the sjs became quite close. The Swedish School's development under Ekblad's leadership, and her role in making it into a hub for Scandinavians living or traveling in the region, would have given the Swedish headmistress a social status that opened doors to the influential American Colony. Ekblad's friend, the Swedish-Finnish anthropologist Hilma Granqvist (189o-1972), famous for her ethnographic work in Palestine in the 1920s, describes the matriarchal head of the Colony, Bertha Spafford Vester, as a beautiful, charming and warm woman. Vester's verve and connections helped Granqvist establish her field work in the village of Artas, close to Bethlehem. Spafford Vester's connectedness and talents as a social

24 Okkenhaug, "Signe Ekblad and the Swedish School," 147-162.

25 Birkagården, http:www.birkagarden.se.

26 Both Ekblad's and Larsson's official roles and duties meant that they also quite often were the object of the photography as main character or part of a group of important figures. In this manner the Swedes in Jerusalem could be assured that the prominent roles played by Larsson and Ekblad were transmitted to supporters in Sweden without words.

27 Björk, Sverige iJerusalem och Betlehem, 32. Even so, the founder of the sJs, Bishop Henning von Schéele, wrote with sympathy about the Colony in several articles in the sjs journal.

28 Okkenhaug, "Scandinavian Missionaries in Palestine".

29 Swedish author and Nobel laurate Selma Lagerlöf's novel Jerusalem, based on the history of the Swedish members of the American Colony, published in 1902-03, had made the American Colony known in the Scandinavian countries. Lagerlöf had visited Jerusalem and the American Colony herself. 
player would have appealed to Ekblad's professional self. ${ }^{30}$ In addition, by the 1920s, the American Colony was no longer a utopian community. The younger generation was mostly secular. ${ }^{31}$ Concerned with commercial ventures and social relations, their American Colony had become a centre for social events for the upper strata of all Jerusalem and ex-pat milieus. Ekblad accepted invitations to events at the Colony, and members from the leading families in the Colony attended Christmas parties and concerts organised by Ekblad and her staff, thus adding social prestige to the Swedish School. ${ }^{32}$

The links between the sjs and the American Colony contained more than social interaction, however. Larsson, Matson and other (unnamed) photographers photographed the Swedish School and these photographs were printed in the sjs membership journal in order for the Swedish supporters to follow the 'Swedish' cultural (and financial) investment in Palestine. Like Ekblad and the sjs, the members of the American Colony did not proselytise, but engaged in economic enterprises as well as welfare work which was open to all religious communities in the city. Even so, in the inter-war period, the Colony focused mainly on the Arab population. ${ }^{33}$ Thus, the younger Swedish members of the Colony shared with Ekblad a yearning to contribute to modernising Palestinian, Arab society. ${ }^{34}$ Both parties took photographs that tell a social history from a local, Palestinian context. This is in accordance with Issam Nassar who argues that 'Local photography is any photography that represented social life in Palestine as opposed to biblical landscapes or Zionist photography that

30 Sofia Häggman, Hilma Granqvist. Antropolog med hjärtat i Palestina (Vasa; SFV, 2017), 55.

31 Comment by Rachel Lev.

32 See Bertha Spafford Vester, Our Jerusalem: An American Family in the Holy City, 1881-1949 (New York: Doubleday, 1950).

33 Abigail Jacobson, "American "Welfare Politics": "American Involvement in Jerusalem During World War I," Israeli Studies 18, no. 1 (2013): 56-76; Awad, "Waiting for the Second Coming," 107-108. See also Heleen Murre-van Den Berg, "Our Jerusalem”: Bertha Spafford Vester and Christianity in Palestine during the British Mandate", in Britain, Palestine and the Empire: The Mandate Years, ed. Rory Miller (Farnham/ Burlington: Ashgate, 2010), 328-331.

34 The American Colony created a School of Handicrafts and Dressmaking for girls in 1918 and a hospital for children (the Spafford Children's Center). Bertha Spafford Vester, Our Jerusalem. An American Family in the Holy City, 1881-1949 (London: Evans Brothers Limited, 1951), 328: the School of Handicrafts and Dressmaking had been established during the war. "After the war it was enlarged and added plain sewing and dressmaking classes. Instruction given in the three R's in Arabic, and English was taught. Needle lace and embroidery, using traditional patterns characteristic to the country, were developed. Later we added knitting, crocheting, and weaving." 
was exclusively representing the Jewish settlement project in Palestine. ${ }^{35}$ Even so, local photographs also dealt in the Biblical, as seen in Rona Sela's chapter in this volume.

The American Colony's Photo Department can be seen as both foreign with photographers like Larsson and Matson who were born in Sweden and local, with its history and roots in Jerusalem. ${ }^{36}$ The same might be said of Ekblad who immigrated to Palestine as a young adult and lived and worked in Jerusalem for twenty-six years. I would argue that Larsson, Matson and Ekblad are 'local photographers'. 'It is the context in which the images were produced, exchanged, viewed and assigned meanings that must be placed at the core of our attempt to discern what is local from what is not. ${ }^{37}$ What was the social context in which the sjs images were produced? What stories were they intended to tell the viewer, that is, the supporters in Sweden?

\section{'The Great Gift': The Swedish School in Jerusalem}

Our hearts are filled with happiness and thankfulness towards God and people for the great gift to us and our work, that are contained in the words "Swedish Jerusalem Society's plot and school building in Jerusalem". ${ }^{38}$

The gift referred to by the sjs secretary in Uppsala was a large testimonial endowment from the founder of the sjs, Bishop Knut Henning G. von Schéele (1838-1920) and his wife, Anna Ekman Schéele (1850-1925). ${ }^{39}$ The donation was explicitly assigned to the purchase of a building in Jerusalem suitable for a school and created a financial and psychological base necessary to develop the Swedish school into a competitive primary school. This was the ambition of Signe Ekblad and her ally, Hol Lars (Lewis) Larsson, by now the Swedish Consul in Jerusalem. ${ }^{40}$ At the time, Larsson who had been fifteen years old when he left Sweden with his mother and siblings in 1896, had lived thirty years in the American Colony in Jerusalem. Swedish-American connections were, however, not unusual at the time. There were strong links between Sweden and Swedish-American milieus in the United States, not least based Issam Nassar, "Early local photography in Jerusalem," History of Photography 27, no. 4 (2015): 325 .

$36 \quad$ I thank Sary Zananiri for making this point.

37 Nassar, "Early local photography in Jerusalem," 324.

38 Svenska Jerusalemsföreningens Tidsskrift no. 4 (1926): 194-195.

39 Svenska Jerusalemsföreningens Tidsskrift no. 3 (1926).

40 Okkenhaug, "Att avresa till Jerusalem som lärarinna," 121-134.
} 
on a shared Lutheran Protestantism. In the United States, Swedish immigrants tended to keep the Lutheran religion and links to the Swedish state church. ${ }^{41}$ The importance of Swedish-American ties was also seen among the supports of the Swedish Jerusalem's Society: from the beginning the organisation had a number of Swedish-American members, and Swedish-American congregations funded part of the sJs's new school complex in Jerusalem. ${ }^{42}$ Thus, Larsson's American ties did not disqualify him from representing Sweden in Palestine. ${ }^{43}$ The previous Swedish Consul in Jerusalem, Professor Gustaf Dalman, a German citizen and thus disqualified to continue his official role in Palestine after 1918, pointed to both the Swedish roots and deep connections to Palestine, when describing Larsson: 'While Herr Hol Lars Larsson was born in Nås, western Dalarna, he has been in Jerusalem since 1896, has worked his way up to becoming the American Colony's most distinguished landscape photographer and head of its Photo store, is married and soon to be 40 years old. 44

In a similar manner to John Whiting, Larsson became a popular tour guide. Prominent Swedes visiting Palestine raved about this 'ordinary boy from Nås in west Dalecarlia'45 Renowned explorer Sven Hedin travelled with Larsson as his guide during a longer stay in Palestine and was full of praise for Larsson, as one can read in his travel book, Jerusalem. Hedin writes of Larsson:

$[\mathrm{M}] \mathrm{y}$ faithful companion, a better cicerone on earth is not to be found ... He knew every corner of Jerusalem city, every road, village and ruin in the whole of Palestine and Syria. If the choice was mine, I would rather have his knowledge than all the wisdom of Baedeker, for he has travelled the country in all directions many, many times, partly to take photographs for sale to travellers and pilgrims, partly as a tourist guide. ${ }^{46}$

41 More than one million Swedes migrated to the United States between $1885^{-1915}$.

42 Björk, Sverige i Jerusalem och Betlehem, 19, 38. In 1913 there were more than 100 members in the United States.

43 John Whiting, born in Jerusalem with American parents, became the American consul during the same period. See Rachel Lev's article in this volume.

44 Gröndal, The Dream of Jerusalem, 242.

45 Sven Hedin, Till Jerusalem (Stockholm: Bonnier, 1917). 242 of the photographs in the book were taken by Lewis Larsson.

46 Gröndal, The Dream of Jerusalem, 214. "He (Lewis Larsson) was at home with the country's various history and knew his Bible by heart, albeit in English only, which he spoke as easily as Swedish. He spoke German and French without difficulty, and perfectly fluent Arabic. And this Lars Larsson ... was an ordinary boy from Nås in west Dalecarlia, having emigrated at 15 . During the twenty years since then, he had himself acquired his entire store of knowledge." 
Larsson's success as local guide for an increasing number of Swedish tourists, including the Swedish minister in Cairo, Harald Bildt, made the Swedish government offer Larsson the position as official Swedish representative in Palestine. ${ }^{47}$

The Swedish Jerusalem Society was the only Swedish organisation in Palestine and as Swedish Consul Larsson became deeply involved in the development of the Swedish School. Larsson recognised the potential for a larger educational institution catering for the Arab community in Jerusalem. ${ }^{48} \mathrm{He}$ shared this ambition with Ekblad and with the aid of Larsson, Ekblad managed to convince a highly sceptical board in Uppsala that building a new, large school would be sustainable and worthwhile. Ekblad, who had won the support of the Governor of Jerusalem, Edward Keith-Roach, spent summer vacations fundraising in Sweden. ${ }^{49}$ She and Larsson also engaged the architect Hermann Imberger from the German Templar society, who, having grown up in Jerusalem, had invaluable knowledge of local properties, architectural styles and builders. ${ }^{50}$

In early 1926 Larsson came across a house in Musrara, near Prophet Street that was for sale for a reasonable price. ${ }^{51}$ The three agents in Jerusalem, Ekblad, Larsson and Imberger, urged the board in Uppsala to make a swift decision before the two different owners (one of the house and plot, and one of the

47 Larsson, Dalafolk i heligt land, 118-119.

48 Svenska Jerusalemsföreningens Tidsskrift no. 4 (1926): 188. Larsson was in charge of the purchase of land for new school, he negotiated with the seller, based in Istanbul, and he acted as a mediator between the sJs board in Sweden and the American Colony regarding a short-term loan that secured the purchase of the property.

49 Okkenhaug, "Att avresa till Jerusalem som lärarinna," 129.

50 See Ruth Kark, "Missions and Architecture Colonial and Post-Colonial Views. - The Case of Palestine, Altruism and Imperialism in the Middle East," in Occasional Papers, eds. Eleanor H. Tejirian and Reeva Spector Simon (New York: Middle East Institute, Columbia University, 2002), 183-207. Since this plot was not large enough for a good-sized playground, Larsson recommended that they buy the neighbouring property - a plot without a building which was also for sale, for 2000 Egyptian pounds. It was a very good offer, according to Larsson, and Ekblad agreed, pointing to the good qualities of the house as a school building. Larsson had the support of architect Imberger, who guaranteed that this was a good purchase. Svenska Jerusalemsföreningens Tidsskrift no. 4 (1926): 184-185.

51 Svenska Jerusalemsföreningens Tidsskrift no. 4 (1926): 182-188. The owner lived in Istanbul and wanted to sell his property in Jerusalem, asking 4000 Egyptian pounds for the house and plot. "I hope the sjs does not miss this unique opportunity," Larsson wrote to the board (19th February 1926). 6ooo pounds was 110,ooo Swedish kroner. The negotiations were additionally complicated because of the fact that the adjoining property had several owners who all had to agree on the price. 
adjoining property with no building on it) received higher offers. ${ }^{2}$ On 2oth of June, Larsson was finally able to close the deal on one of the properties, which cost the sJs board 3,00o Egyptian pounds. ${ }^{53}$ The board also gave Larsson authority to purchase the adjoining property and he was in charge of the formal procedures to finalise the deals. It would have been very difficult to find and buy a suitable property in Jerusalem without Larsson's experience and knowledge of the city. The board in Uppsala, overjoyed by the fact that the deal was completed, thanked both Ekblad and especially Larsson for succeeding in the difficult negotiations. ${ }^{54}$

Before the building could be used as a school, however, there were repairs to be done..$^{55}$ By mid-October, the Department of Education finally approved the opening of The Swedish School in the newly purchased building. With four school classes, and a total of 107 pupils, it was no longer only a kindergarten. The roof had been repaired, a water tank installed and the area outside was transformed into a modern playground. ${ }^{56}$

With the purchase of the new building the Swedish School had become a serious player in the private educational market in Palestine. Due to lack of state run schools, there was a large number of mission run educational institutions in Palestine. ${ }^{57}$ The Arab school system was far from universal and consisted of government-controlled schools, the large majority being rural schools for boys. ${ }^{58}$ The Mandate authorities did not give priority to education

52 Svenska Jerusalemsföreningens Tidsskrift no. 4 (1926): 184-185. The process was also delayed because the owner of the house wanted to close the deal himself. In order to do so, he had to make the journey from Istanbul.

53 Svenska Jerusalemsföreningens Tidsskrift no. 4 (1926): 186. Larsson sent a telegram to the board in Uppsala: "Send via telegraph 3,ooo Egyptian pounds. School building bought".

54 Svenska Jerusalemsföreningens Tidsskrift no. 4 (1926): 188. Larsson's connections to the American Colony was also of great importance, as 'Vester \& Co, American Colony', promised to lend sjs the necessary sum of money if the money from Sweden did not arrive soon enough.

55 Svenska Jerusalemsföreningens Tidsskrift no. 2 (1928): 36 . By the opening day, October 6th, there were only 6o children attending. The rest had started another school. In Jerusalem there was little loyalty to one school and it was not uncommon for parents to send their child to a number of different schools.

56 Svenska Jerusalemsföreningens Tidsskrift no. 4 (1926): 189-191.

57 In theory open to all religions, there were only Jewish children in the Jewish schools. The use of Hebrew as language of instruction enforced this separation. The Jewish system consisted of government supported schools, and schools under the Vaád Leumi (the Jewish National Council) and Jewish private schools, from kindergarten up to university level.

58 Bowman 2/2/10, St. AP. "A review of Educational Policy 1920-1932". In Palestine, Bowman gave priority to primary schools in the villages. During the Mandate period, there were 75 missionary schools, fourteen British government schools, 412 Muslim public village 
for girls, and especially in urban areas girls' education to a large extent became an arena for private schools (both Christian and Muslim). ${ }^{59}$ Ekblad was aware of the lack of schools for Arabs and especially the few educational opportunities for Arab girls. Her passionate reports from Jerusalem, accompanied with snapshots of children in the school yard, ${ }^{60}$ convinced Swedish supporters that the Swedes were needed among the Arabs. ${ }^{61}$ As we shall see, it was this educational void that would help to fulfil Swedish ambitions and competition against other European powers' humanitarian presence in Palestine. Is it possible to detect something of this in the images?

In her work on photography and transatlantic migration, Sigrid Lien shows how the photographs migrants sent back to Scandinavia visualised emotions and conditions that would be difficult to express in words. ${ }^{62}$ For Signe Ekblad, the process of building a new school house embodied her deep desire to create high quality education for Arab girls. Extremely determined and driven by her professional aspirations, she succeeded. But the fundraising and quarrels with the board, ${ }^{63}$ in addition to running a school and learning Arabic, took it tolls.

and town schools and more than 400 Vaad Leumi Jewish schools (secular and religious) in Palestine. Thomas M. Ricks, "Remembering Arab Jerusalem, 1909-1989: An Oral History of a Palestininan City, its Schools and Childhood Memories", 1. https://www .academia.edu/15767904/Remembering_Arab_Jerusalem_1909-1989_An_Oral_Histroy _of_a_Palestinian_City_Its_Schools_and_childhood_Memories.

59 The Muslim children in towns who received an education for some period or other was as late as 1935 estimated to be for boys $75 \%$ and for girls $45 \%$, while in the villages, $40 \%$ of Muslim boys received any education and only $1 \%$ of Muslim girls. Bowman, $2 / 2$, St. AP. "Memorandum by Government of Palestine: Description of the Educational Systems, Government, Jewish and Private, and Method of Allocation of Government Grants, 1936." Enaya Hammad Othman, Negotiating Palestinian Womanhood. Encounters between Palestinian Women and American Missionaries, 1880s-1940s (Lanham/Boulder/ New York/London: Lexington Books, 2016), 13: the government schools provided education to approximately 20,288 students, with only 942 of those being girls. Othman quotes an article by Khalil Totah, "Education in Palestine"; The Annals of the American Academy of Political and Social Science, 163 (September 1932), 156.

6o Unlike many of the photographs in the Svenska Jerusalemföreningens Tidsskrift, these are not credited.

61 Svenska Jerusalemföreningens Tidsskrift, no. 1 (1923): 6-7.

62 Sigrid Lien, Lengselens bilder (Oslo: Scandinavian Academic Press, 2007), 21. English translation: Pictures of Longing. Photography and the Norwegian-American Migration (Minneapolis/London: University of Minnesota Press, 2018).

63 Häggman, Hilma Granqvist, 166. 
By 1930 Hilma Granqvist noted that 'Signe E. has created an adorable creation, her school, but has herself been damaged'.64 During her years in Palestine, Ekblad suffered from fever and headaches. These health issues might explain her serious demeanour in most of the photographs she appears in.

Ekblad's passion for her school manifested itself in her reports and articles to the sjs supporters, where she went into great detail about the process of transforming the old building into a schoolhouse. These reports were accompanied by photographs that visualised the transformation of the property into a modern school for young children. This process was made possible by local workmen. In Ekblad's texts, these workmen, when mentioned at all, are described as 'labourers' and not by name (the exception being 'our architect Imberger', who is not seen in any of the photographs). However, in the accompanying photographs, the active people at work are local carpenters and masons. When documenting the erection of a beautiful stone wall that was to encircle the property Ekblad focused on the masons at work. In the text accompanying the picture, it becomes clear that the fence was paid for by money from the sale in Sweden of embroidery, postcards with dried flowers from Jerusalem and other craft items made by the teachers and Ekblad. ${ }^{65}$ The photographs gave the readers and donors a tangible impression of their contribution not only to education in a country that lacked state schools for its majority population, but also to Swedish-owned land in Palestine, verifying that Sweden was a confident player among other nations' mission enterprises. In addition, the image of building is not only a documentation of an ongoing process, but also an expression of Ekblad's longing for the future and the completion of a new and competitive Swedish School. ${ }^{66}$

In her written reports Ekblad was often concerned with the aesthetics of life in Jerusalem and her photographs also show an awareness of what she finds beautiful and harmonious, including the new wall around the property, the school's garden with its leafy trees and the new playground. ${ }^{67}$ In the caption of a photograph taken by Ekblad printed in the sjs journal, she has written: 'The School's beautiful plot fence and (tomtmur och port) gate under construction. In the background one can see the school house, framed by the leafy trees' ${ }^{68}$

While Ekblad was an amateur taking pictures, she shared a desire to photograph Palestinian landscapes - rural and urban - with Hol Lars (Lewis)

\footnotetext{
64 Häggman, Hilma Granqvist, 166.

65 Svenska Jerusalemsföreningens Tidsskrift no. 1 (1927): 17-18.

66 Lien, Lengselens bilder, 47.

67 See Okkenhaug, "Att avresa till Jerusalem som lärarinna."

68 Svenska Jerusalemsföreningens Tidsskrift no. 1 (1927): 59.
} 


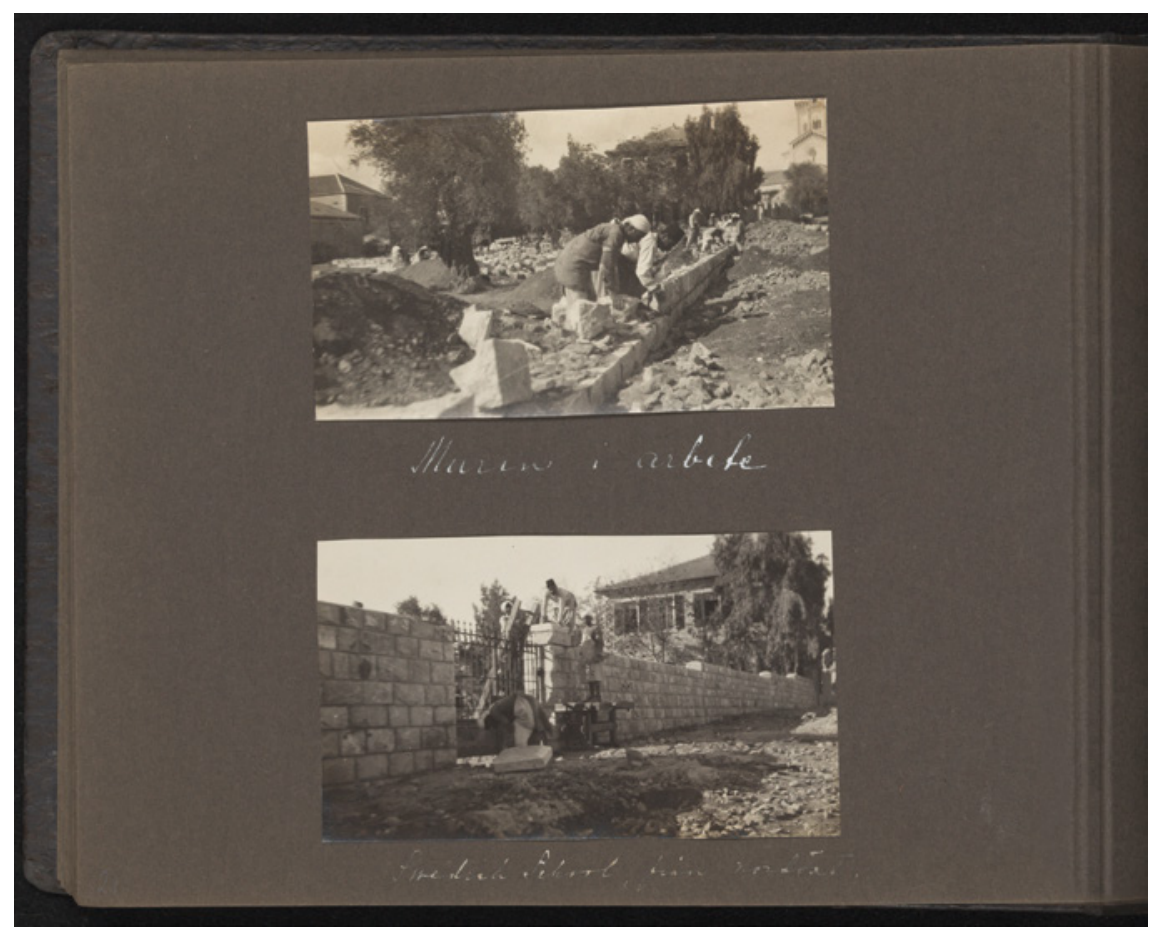

FIGURE 3.3 Photograph of the ongoing work at the Swedish School, Signe Ekblad. Swedish Jerusalem Society's Collection, 396354 IMAGE COURTESY OF UPPSALA UNIVERSITY LIBRARY

Larsson. ${ }^{69}$ Even so, Larsson's photographs of the Swedish School also include the building process, the new school building and the garden. In addition, Larsson's photographs printed in the sJs journal also include a landscape photograph of the school children on an Easter outing in March $1926 .^{70}$ In the foreground is a large, old olive tree, giving a sense of 'eternity' or reference to Biblical times. The children and teachers are seen at a distance gathered in a large circle in an open landscape. Thus, Swedish audiences might see that they were funding an institution that educated the younger generation of Palestine while at the same time being located in a biblical landscape.

69 The Dream of Jerusalem, 242.

70 SvenskaJerusalemsföreningens Tidsskrift no. 2 (1926): 77. 


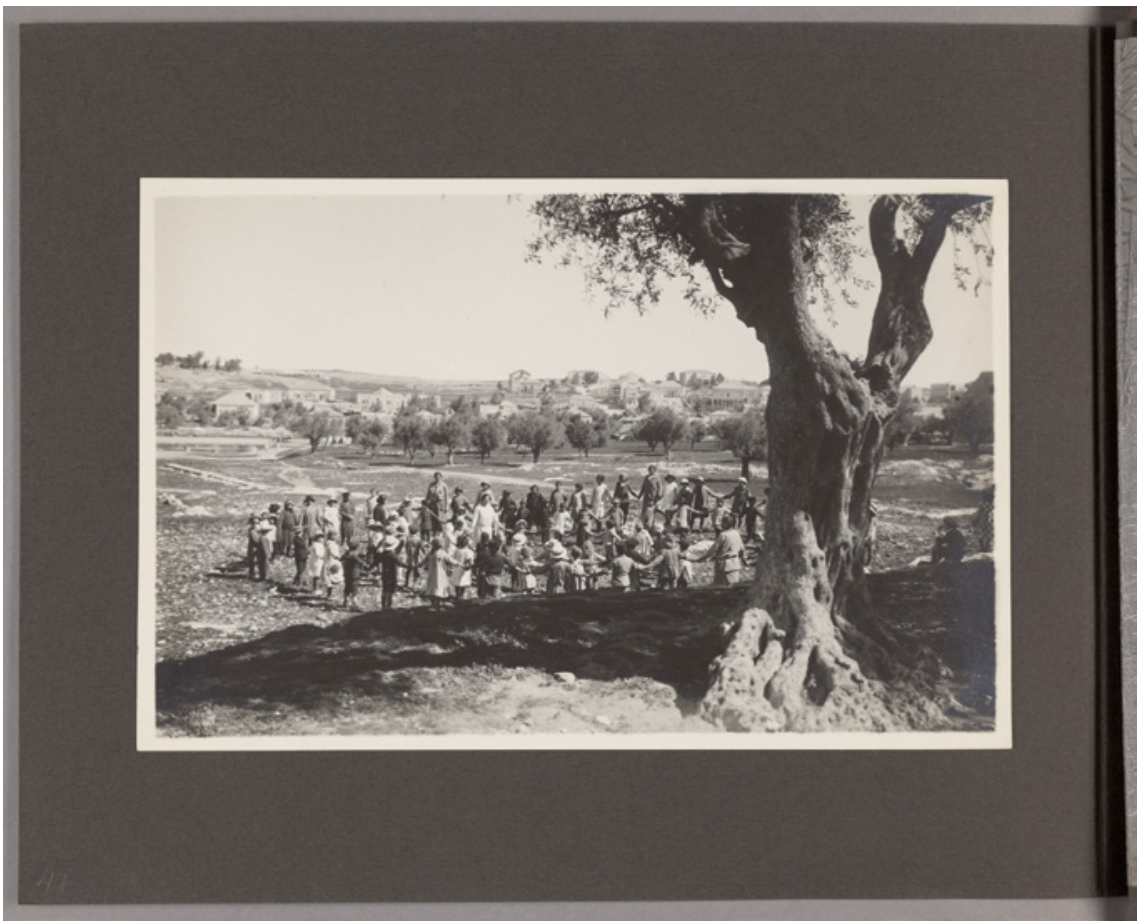

FIGURE 3.4 Children and teachers from the Swedish School on an Easter outing, 1926. Hol Lars (Lewis) Larsson. Swedish Jerusalem Society's Collection, Album No. 9, 293849 IMAGE COURTESY OF UPPSALA UNIVERSITY LIBRARY

In 1927 the sjs journal printed a watercolour by the Swedish artist Elsa Beskow, whose illustrated children's books were extremely popular in the Nordic countries. The picture was made for the Swedish School and it depicted a Palestinian boy and girl, each holding a Swedish flag, in front of a low stone wall (similar to the one around the Swedish school). Behind the wall was a Middle Eastern urban landscape that linked the Swedish School to the city of Jerusalem. On the bottom of the picture was written 'Welcome to the Swedish Jerusalem Society's School'. While the motif was Palestinian, the style was distinctly Beskow - the way she created fairy tales in words and paintings for Swedish children. The original of the watercolour hung in the St John's hotel, while the sJs sold copies in order to raise funds for the school. ${ }^{71}$

$71 \quad$ Svenska Jerusalemsföreningens Tidsskrift no. 1 (1927): 27. 
Elsa Beskow was a prominent and active supporter (together with Selma Lagerlöf among others) in Sweden of the sJs work in Jerusalem. She was married to the Swedish minister Nathaniel Beskow, whose leadership of Birkagården, from 1912 to 1946, includes Ekblad's three years there as a social worker (from 1912 to 1915). $\cdot^{72}$ If it is this connection between Ekblad and Nathaniel Beskow that made Elsa Beskow paint for the Swedish School, is not known. However, her picture of the Swedish School connects Sweden with Palestine in a manner that would have resonated with the Swedish viewers and donors.

There are several photographs taken by photographers from the American Colony that might have been inspired by, if not Beskow's style, at least references to Swedish aesthetics. In connection with the move to the new school building in 1926, the sJs journal printed a photograph taken by Hol Lars (Lewis) Larsson of the youngest children, around 30, and a teacher (probably Ekblad) in the background. The children are all wearing wide, white hats and each child is carrying a large framed picture, poster or basket, helping with the move. They are standing in a relaxed line in the school yard beside the wall. In the background are leafy trees. ${ }^{73}$ The small children in their wide hats reminiscent of Beskow's child depictions of 'Putte' in the blueberry woods.

Another image printed in the sjs journal and credited to the American Colony, is from 1928 and the laying of the foundation stone for the new school building, one of the most important events in the sJs' history. ${ }^{74}$ In this photograph, Ekblad is seen leaning on the stone together with six young Palestinian children, three girls and three boys. The inscription on the large stone is in Swedish and Arabic and reads: 'Foundation stone laid down the 23rd of March $1928{ }^{\prime 75}$

Another of these images eternalised by a photographer from the American Colony was used in both the sjs journal and in Palestinska dagar. The photograph is from around 1929, when the new school building was finished. The building, impressive with its two storeys, large windows and a gallery, is seen with a Swedish flag high above the flat roof. There are trees on both sides. A large group of children led by a teacher are seen in the front of the building,

72 Okkenhaug, "Att avresa till Jerusalem som lärarinna," 126.

73 Svenska Jerusalemsföreningens Tidsskrift no. 3 (1926): 178. The caption underneath the image says: "The caravan of the smallest with pictures and on their way to the school's newly purchased home".

74 Svenska Jerusalemsföreningens Tidsskrift no. 1, (1928), 43.

75 Swedish Jerusalem Society's Archives, Uppsala University Library. Published in Svenska Jerusalemsföreningens Tidsskrift no. 1 (1928): 43. 


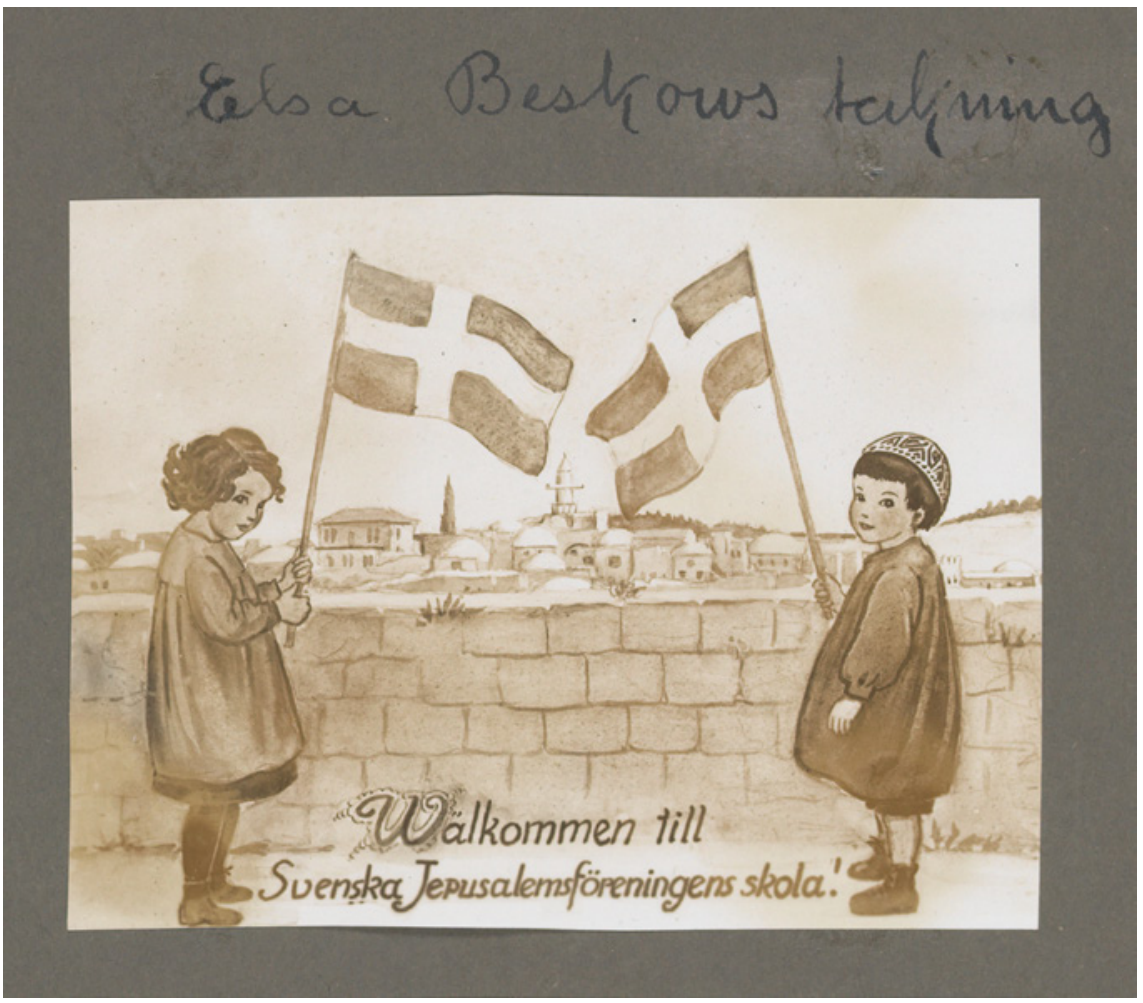

FIGURE 3.5 'Welcome to the Swedish School', 1927. Reproduction of a watercolour by Swedish artist Elsa Beskow with caption. Swedish Jerusalem Society's Collection, 396356 IMAGE COURTESY OF UPPSALA UNIVERSITY LIBRARY

standing in a half circle doing Swedish gymnastics. ${ }^{76}$ It is an aesthetically pleasing image and one of a few with the Swedish flag.

Yet another photograph taken by an American Colony photographer in 1930, shows the inside of the new school building where a group of children and two teachers stand facing the photographer, while a teacher is playing the organ. ${ }^{77}$ The youngest children are standing on the stairs with Ekblad and another teacher, making a half circle with sunlight coming in from a window above. The photograph captures white walls with an evergreen plant on a shelf, and a beautiful tiled floor that dominates the front of the picture. ${ }^{78}$ The caption says 'Morning prayer in the hall', thus verifying the Christian character of the school

76 Svenska Jerusalemsföreningens Tidsskrift, no. 1, 1929, 79.

77 Lindqvist, Palestinska dagar, 69.

78 Lindqvist, Palestinska dagar, 69. Photograph from American Colony's Publishers. 


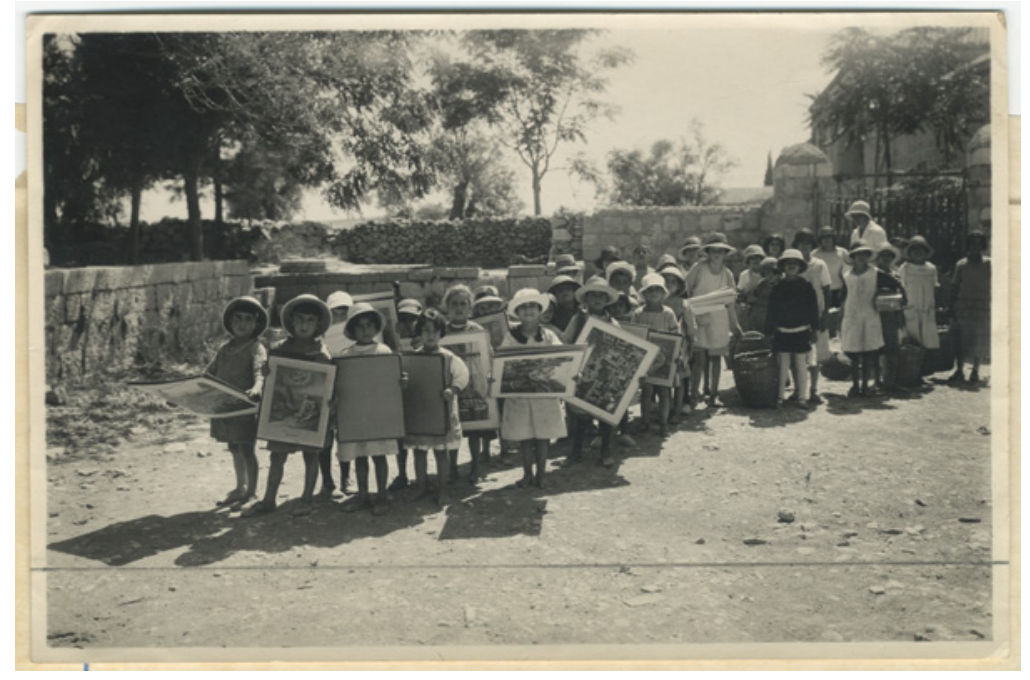

FIGURE 3.6 The youngest children and teacher (Ekblad?) in connection with the move to the new school building, 1926. Hol Lars (Lewis) Larsson. Swedish Jerusalem Society's Collection, 92997

IMAGE COURTESY OF UPPSALA UNIVERSITY LIBRARY

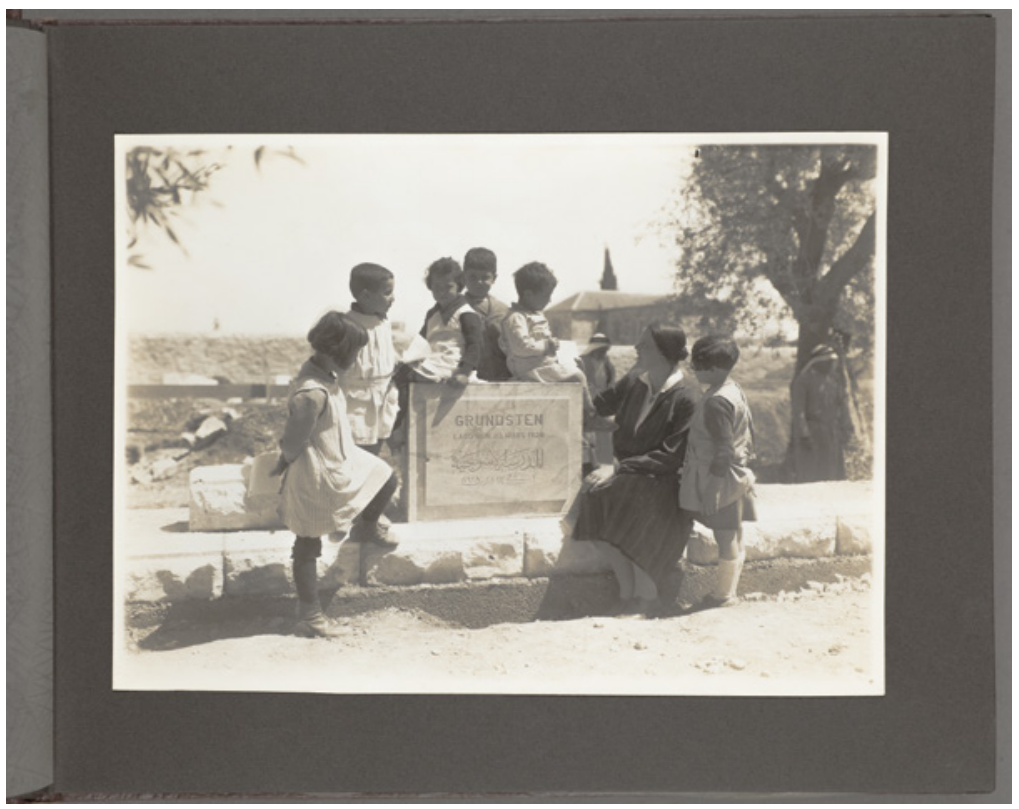

FIGURE 3.7 Signe Ekblad and children with foundation stone for the new building, March 1928. The American Colony Photo Department. Swedish Jerusalem Society's Collection, Album No. 9 IMAGE COURTESY OF UPPSALA UNIVERSITY LIBRARY 


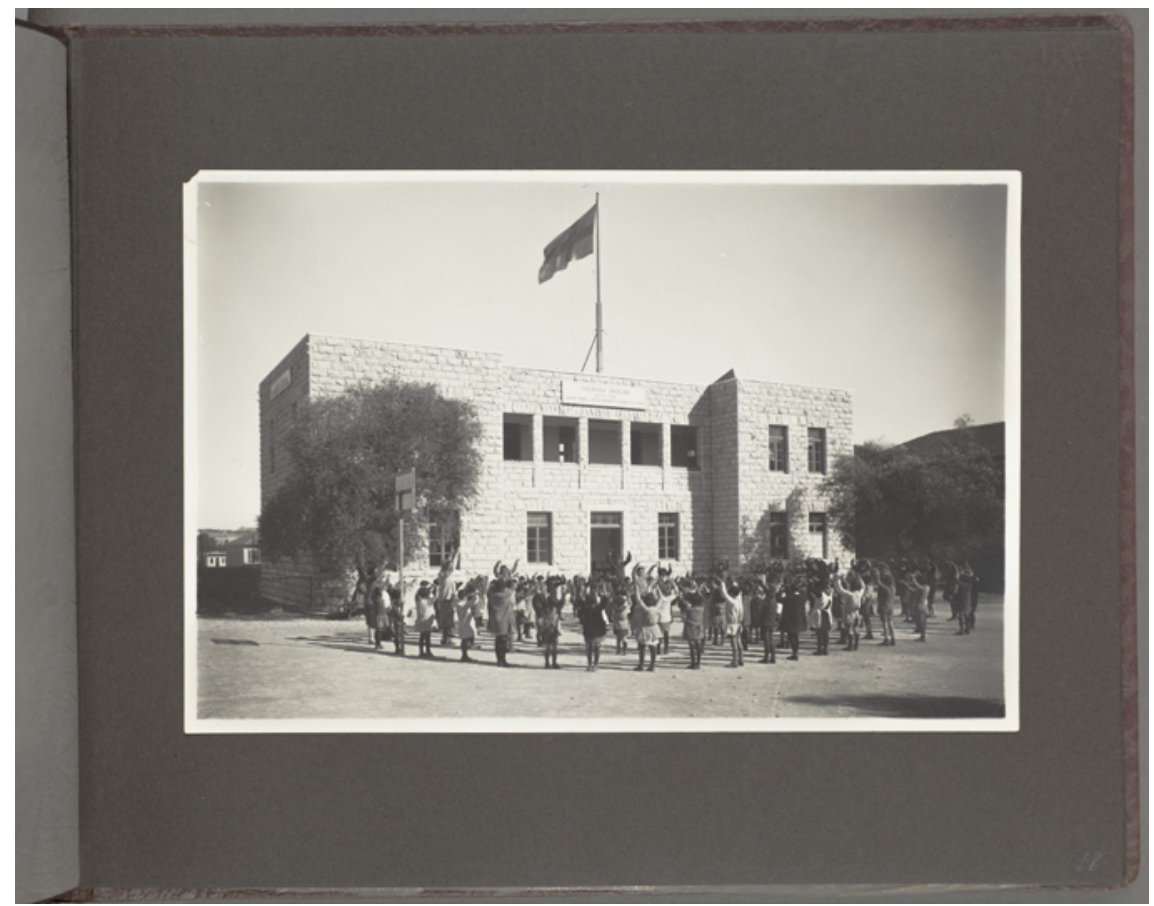

FIGURE 3.8 The new building at the Swedish School, pupils and teachers doing Swedish gymnastics outside in the school yard, 1928. The American Colony Photo Department. Swedish Jerusalem Society's Collection, Album No. 9, 194135 IMAGE COURTESY OF UPPSALA UNIVERSITY LIBRARY

for a Swedish audience. Even so, the image created is a sense of happy Swedish childhood found in Beskow's books for children transferred to a Palestinian setting. It might also remind one of the works of one of Sweden's most popular and internationally known artists, Carl Larsson (1853-1919). ${ }^{79}$ Larsson, who was an inspiration for Elsa Beskow's illustrations, is mainly known for his watercolours of idyllic family life. He was hugely influential in Sweden and beyond. Carl Larsson played a prominent role in the Swedish national handicraft movement and the local folklore movement (both ideologically influenced by the arts and crafts movement in England). In Elisabeth Stavenow-Hidemark's words: 'Carl Larsson and his world were considered the height of Swedishness' ${ }^{80}$ Larsson's

79 Lena Larsson, "The Larsson Design Legacy: A Personal View," in Carl and Karin Larsson. Creators of the Swedish Style, eds. Michael Snodin and Elisabeth Stavenow-Hidemark (Boston/New York/Toronto/London: Little, Brown and Company, 1998), 227.

8o Elisabeth Stavenow-Hidemark, "Carl Larsson's images - mass publication, distribution and influence," in Carl and Karin Larsson. Creators of the Swedish Style, eds. Michael 
prints and paintings would have been familiar to the Swedish photographers at the American Colony and anyone who visited The Swedish School would have seen reproductions of Carl Larsson's work on the walls of the classrooms. ${ }^{81}$

It is possible that Larsson or Eric Matson or some of the other Swedish-born photographers were influenced by the nostalgia of the Swedish emigrant. A nostalgia underlined by both Beskow and Carl Larson's pictures of idyllic childhood in picturesque images of Swedish forests, lakes and rural homes. Even so, this might also be a form of remaking of Palestine in the image of Sweden that connects Swedish viewers to the Palestinian landscape. ${ }^{82}$ Photographs depicting the practical, modern aesthetics of the new school building, for example, can be seen as part of the implementation of Swedish cultural diplomacy. For the viewers in Sweden, this 'Swedish vision of Palestine' would have emphasised the role of the sJs' School as 'Swedish', thus contributing to a feeling of a national and worthy Swedish presence in Palestine.

Carl Larsson's aesthetics might also have inspired images taken of the Sunhut - a shelter for warm or rainy days. Desired by Ekblad and her colleagues, and designed by architect Imberger, the Sunhut was financed by Swedish immigrants in North America. The shelter was constructed by Palestinian workmen and Hol Lars (Lewis) Larsson dealt with all practicalities related to building in Jerusalem. ${ }^{83}$ The end result was a pleasing, permanent construction and Ekblad emphasised both its every day, useful sides and its aesthetics when describing it to Swedish supporters: 'It is all very practical, but also particularly nice. ${ }^{84}$

In this photograph, some teachers are examining schoolgirls' eyes in the Sunhut. Also, here Ekblad has a distinct presence, not at the front, but looking at the camera from the back. Not tending to any of the girls, Ekblad looks as if she is in charge of the whole operation. The majority of the young girls, all wearing the same kind of blue work-dress, are lined up to be checked, but it is not a very orderly line, as some of them are turned away from the camera, while the four girls sitting on the bench to the right of the picture look impatient and two of them have their heads turned towards the fence behind them. The motif of lively children reminds one of the energic children in many of Carl Larsson's pictures. This photograph is hand-coloured: the green leaves outside the hut give a beautiful, subdued light creating a harmonious impression

Snodin and Elisabeth Stavenow-Hidemark (Boston/New York/Toronto/London: Little, Brown and Company, 1998), 218.

81 Okkenhaug, "Att avresa till Jerusalem som lärarinna," 128-129.

82 I would like to thank the reviewer for making this point.

83 Svenska Jerusalemsföreningens Tidsskrift no. 1 (1927): 8, "Solhyddan", The Sun Shed.

84 Svenska Jerusalemsföreningens Tidsskrift no. 4 (1926): 189 . 


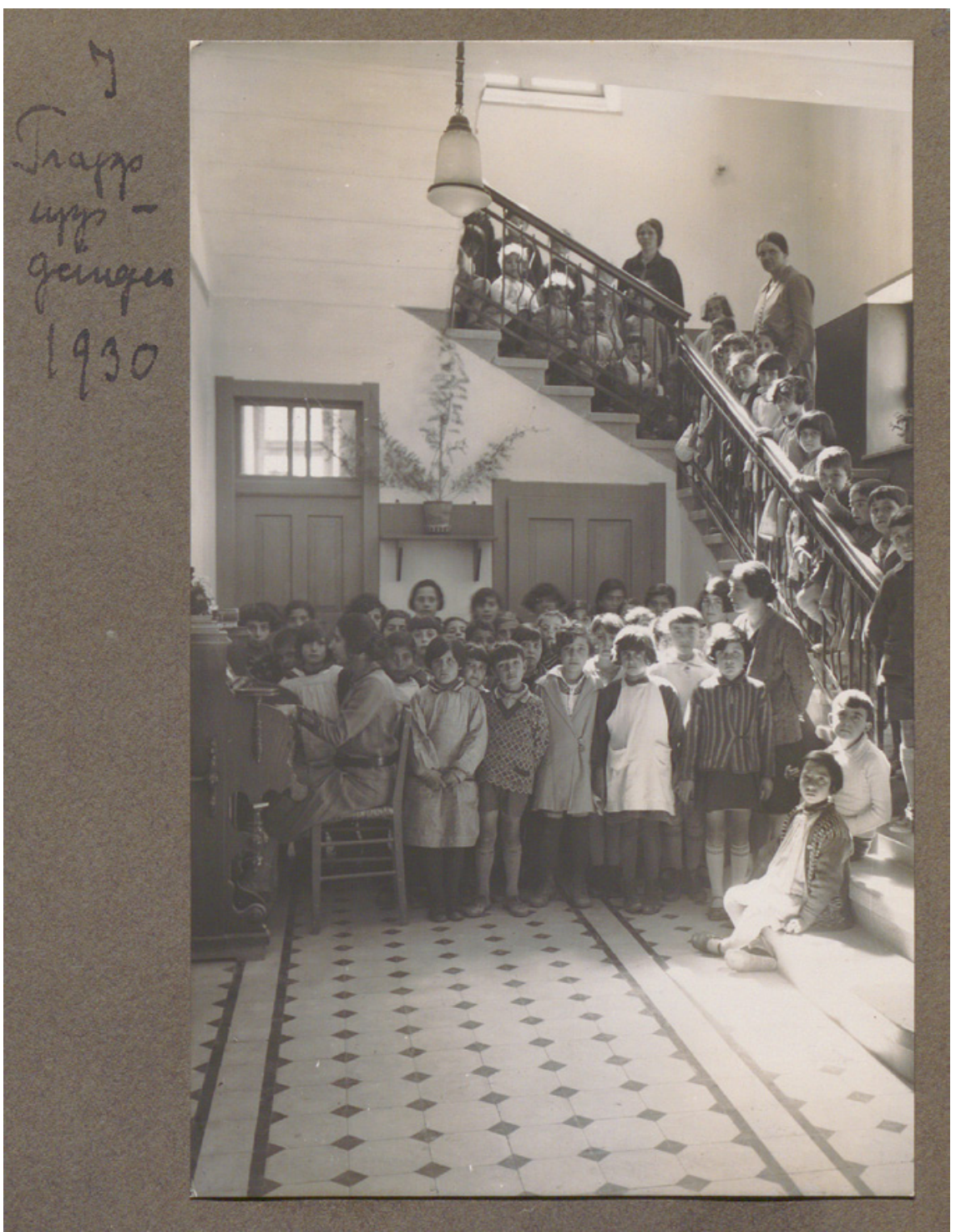

FIGURE 3.9 The scene is from the hallway of the new building at the Swedish school, with children and teachers. Signe Ekblad is standing in the stairs, right, 1930.

The American Colony Photo Department. Swedish Jerusalem Society's Collection, Album No. 1, 293845

Note: Held in Uppsala University Library at the Swedish Jerusalem Society's Collection, Swedish Jerusalem Society's photo album 1, p. 3o. Retrieved from https://www.alvin-portal.org/alvin/imageViewer.jsf?dsId=ATTACHMENT -ooo1\&pid=alvin-record:293845

IMAGE COURTESY OF UPPSALA UNIVERSITY LIBRARY 


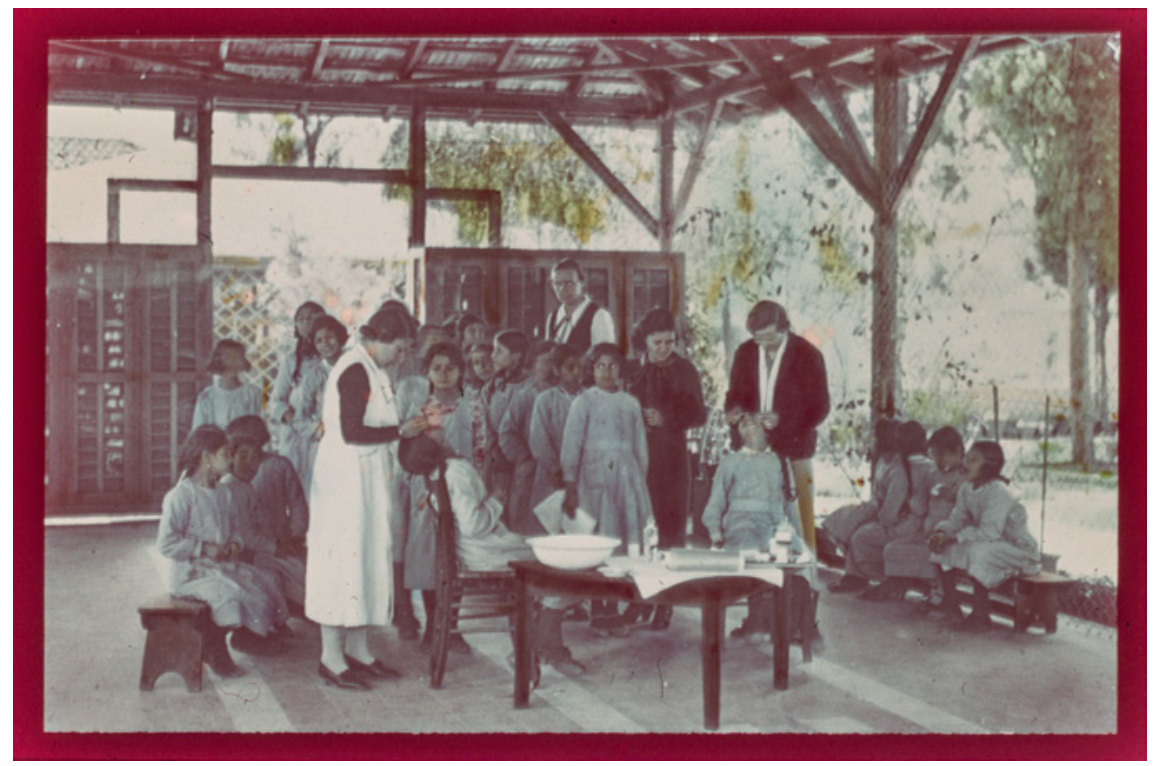

FIGURE 3.10 Teachers examining schoolgirls'eyes in Sunhut. The American Colony Photo Department. Swedish Jerusalem Society's Collection, 293996 IMAGE COURTESY OF UPPSALA UNIVERSITY LIBRARY

against the pale blue dresses of the girls and the table with a 'still life' of a white water-bowl, white napkin and medical equipment.

In a comment on these coloured photographs, Sary Zananari pointed out that 'Compared to other American Colony hand-coloured photographs (which aim for realistic/hyper-realistic renderings), these are much softer and pastel' ... These photographs 'are also much more about something of an impression, rather than reality, despite the slightly clinical nature of what is depicted. ${ }^{85}$ This observation speaks to the Swedish aesthetics of both Beskow's and Carl Larsson's watercolours.

When compared to photographs of other motifs, however, these photographs are very similar to the work of other photographers from the American Colony. ${ }^{86}$ Rachel Lev characterises the creative work of these photographers as art photography. In other words, it is not possible to know if these

85 Sary Zananari commenting on a draft version of this article, 1oth of November 2019. I thank Sary Zananari for his important insights.

86 For example, two women creating lace artifacts with the view of the Dome of the Rock in the background, at the American Colony Industrial School, in Jerusalem circa 1930. See Pelletier, "Jerusalem's religious pilgrims." 
photographs were inspired by Swedish artists, but it is possible that Larsson or Eric Matson or some of the other Swedish-born photographers were influenced by the nostalgia of the Swedish emigrant. Even so, this might also be a form of remaking of Palestine in the image of Sweden that connects Swedish viewers to the Palestinian landscape. ${ }^{87}$ Photographs depicting the practical, modern aesthetics of the new school building, for example, can be seen as part of the implementation of Swedish cultural diplomacy.

Ten years later, photographs from the Swedish School have a totally different rendering, as black-and white documentary photographs of relief work for children on the school premises. No longer a time for yearning for an imagined rural Scandinavian idyll, the war-like situation in Palestine (and in parts of Europe) called for different images and ways of portraying Swedish welfare in Jerusalem.

\section{5}

The Green Hall: Relief, Food and Care

During the Arab Revolt from 1936 to 1939 the Swedish school added relief and food distribution to its activities. ${ }^{88}$ This humanitarian work is the motif of several photographs. In the fall of 1937, since the food provision in the Old City did not meet the local population's needs, Ekblad and some of the female Arab staff decided to build a soup kitchen on the school grounds. ${ }^{89}$ While not receiving news from the board in Uppsala, Ekblad interpreted the lack of response as approval for building a soup kitchen. She raised the money that was needed and again Palestinian carpenters and other workers were able to realise the headmistress' ambitions. Painted green inside and out, the timber hall was formally named the Green Hall on King Gustav's 8oth birthday on 22nd June, $1938 .{ }^{90}$ Originally open only to the school's poorest pupils, the soup kitchen was soon extended to include younger sisters and brothers. The photographs from

$87 \quad$ I would like to thank the reviewer for making this point.

88 Letter from Signe Ekblad to her brother Martin Ekblad, the Swedish School, Jerusalem, 23 April, 1936. I would like to thank Signe Ekblad's family for kindly giving me access to these sources.

89 Uppsala University Library, Svenska Jerusalemsföreningen's Archives. Letter from S. Ekblad to the SJF Board, December 21, 1936. Already in December 1936, Ekblad had written to Uppsala suggesting that she use some of the school's savings to assist 'Arab and Jewish children in distress'. Uppsala University Library, Svenska Jerusalemsföreningen's Archives. Letter from S. Ekblad to the SJF Board, December 7, 1937.

9o Inger Marie Okkenhaug, "Setting the Table at the Swedish School in Jerusalem: Food Distribution and Transnational Humanitarianism in Mandatory Palestine," in Food and Foodways in the Middle East, ed. Nefissa Naguib (Ramallah: Bir Zeit University and Lower Jordan Series, 2009), 121-127. 
the Green Hall depict a vital part of the attempt at bringing Swedish modernity to Palestine. In several photographs children and their mothers are seen sitting by tables, row after row in the Green Hall, waiting to be fed. These images give the impression of an efficient and well-organised Swedish relief effort. Ekblad is the dominant individual distributing food tickets and guarding access to the food. However, the educational aspect of the project was important and the girls learned how to cook and eat nutritious food. ${ }^{91}$ This is reflected in some of the photographs where girls are the main actors. In a similar manner to photographs of girls in the American Colony's Orphanage, as shown by Jacobson in this volume, in the sjs photographs Palestinian girls are laying the table, eating and drinking and washing dishes. Thus, conveying to the Swedish supporters that these young girls who put in their share of work, were exposed to the Protestant work ethic and thus were deserving of Swedish aid. In addition, the photographs document that the poorest of girls at the Swedish School were taught 'home economics', a subject familiar to Swedish and as well as Swedish-American supporters. Ellen Fleischmann, in her work on American mission and home economics teaching in Lebanon in the interwar period, points to the global character of this 'educational, social and vocational movement that aimed to modernise, professionalise, and make scientific female domesticity'.92 Teaching home economics was part of the wider welfare provided by the Swedish School. In Fleischmann's words: 'the praxis involved in implementing home economics resembled social work.93 Thus the soup kitchen was more than charity: in the photographs we see young Palestinian girls being taught domesticity by a Swedish woman, ensuring Swedish home audiences that what was seen as Nordic values of modern housekeeping were transmitted to the Middle East. These photographs, capturing the humanitarian Swedish presence in Palestine exemplify the implementation of Swedish cultural diplomacy. In this instance it is a female who mediates Swedish cultural values and customs to young Palestinian girls. The image thus emphasises that interwar Nordic colonial practice was not only a male arena.

\footnotetext{
91 Signe Ekblad, Lyckliga Arbetsår i Jerusalem (Uppsala: J.A. Lindblad, 1949), 18-19.

92 Ellen Fleischmann, "At Home in the World: Globalizing Domesticity through Home Economics in the Interwar Years," in Transnational and Historical Perspectives on Global Health, Welfare and Humanitarianism, eds. E. Fleischmann, S. Grypma, M. Marten and I.M. Okkenhaug (Kristiansand: Portal Academic, 2013), 158-159, 161. Ibid.
} 


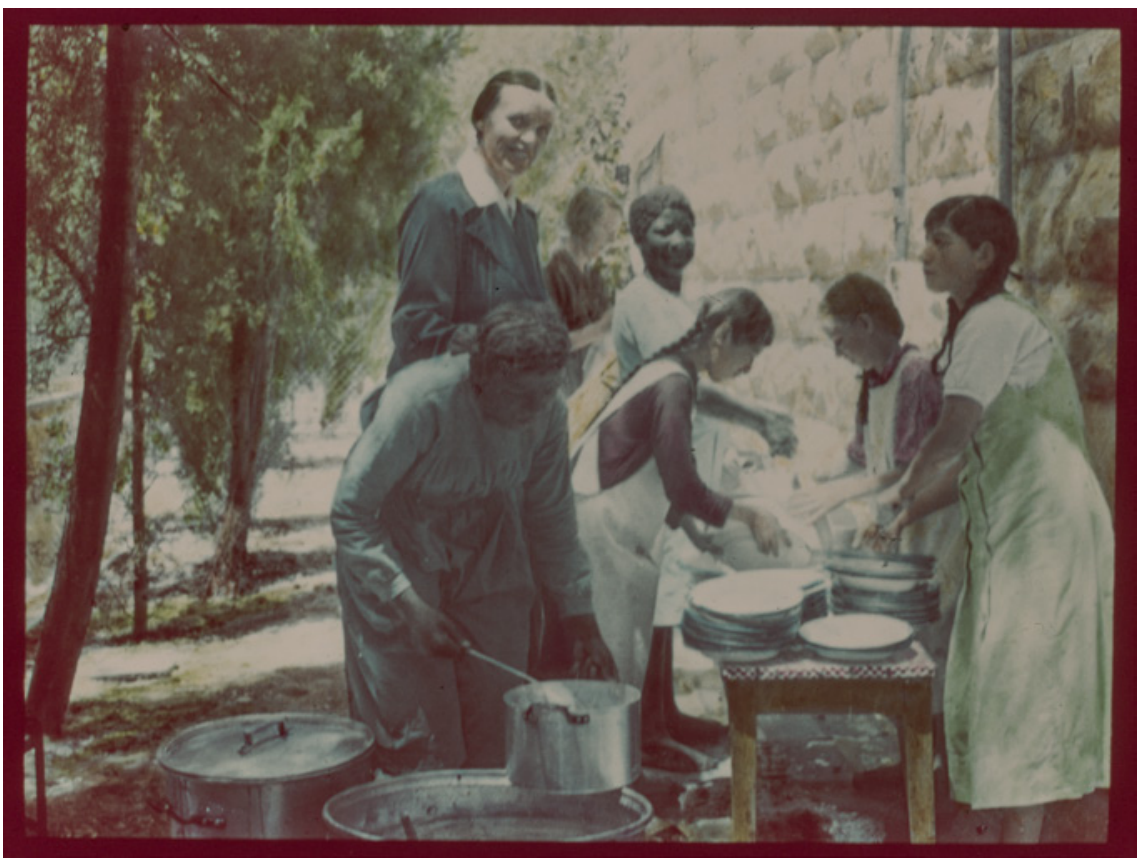

FIGURE 3.11

Girls and teachers (Signe Ekblad to the front) washing up at the Swedish school's soup kitchen the Green Hall, 1939. Eric Matson. Swedish Jerusalem Society's Collection, 293998

Note: Held in Uppsala University Library at the Swedish Jerusalem Society's Collection. Retrieved from https://www.alvin-portal.org/alvin/imageViewer .jsf?dsId=ATTACHMENT-ooor\&pid=alvin-record:293998.

IMAGE COURTESY OF UPPSALA UNIVERSITY LIBRARY

Photographs of the Swedish School in Jerusalem in the interwar period were intended for a Swedish audience of potential donors. The photographs visualised the imagined need for a Swedish presence in 'The Holy Land' and the tangible results the Swedish engagement had in the country, thus manifesting Swedish claims to a national presence in the Palestine. While the written texts to some extent convey a Christian motivation for a Swedish presence in the Holy Land, the photographs do not tend to dwell on ahistorical Biblical motifs. Instead, they convey a message of Swedish modernity. Complementing printed reports, the photographs underlines the message that Sweden as a European nation had a mission to develop Palestine. This at the same time as motives seem to have been inspired by the late romantic style of Swedish artists Elsa 


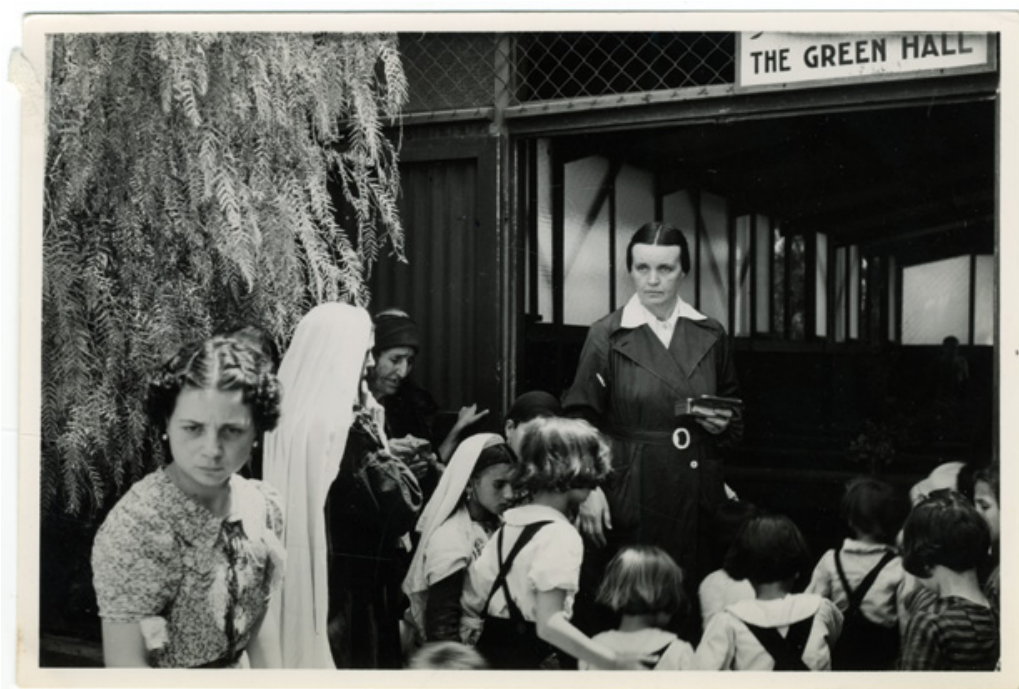

FIGURE 3.12 Signe Ekblad giving out tickets to mothers and children at the soup kitchen Green Hall, Jerusalem, May 1939. Eric Matson. Swedish Jerusalem Society's Collection, 92985 IMAGE COURTESY OF UPPSALA UNIVERSITY LIBRARY

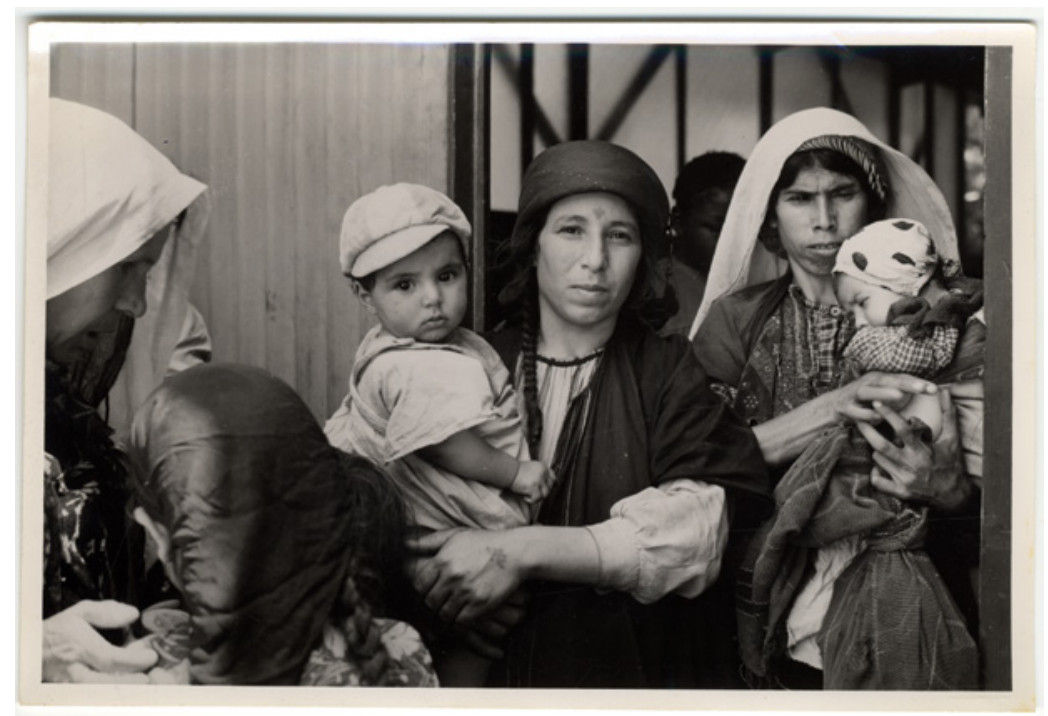

FIGURE 3.13 Mothers and children at the food distribution for children at the Swedish School, May 1939. Eric Matson. Swedish Jerusalem Society's Collection, 93033

Note: Held in Uppsala University Library at the Swedish Jerusalem's Society's Collection. Retrieved from https:/www.alvin-portal.org/alvin/ imageViewer.jsf?dsId=ATTACHMENT-oooı\&pid=alvin-record:93033. IMAGE COURTESY OF UPPSALA UNIVERSITY LIBRARY 
Beskow and Carl Larsson, both representing the ultimate 'Swedishness' at the time. Even so, this was not only about a romantic longing, but a form of remaking of Palestine in the image of Sweden that connected Swedish viewers to the Palestinian landscape and people. Photographs depicting the practical, modern aesthetics of the new building at the Swedish School were part of the implementation of Swedish cultural diplomacy. For the viewers in Sweden, this 'Swedish vision of Palestine' would have emphasised the role of the sJs' School as 'Swedish' and underlining that the Swedish presence in Palestine was legitimate and worthy of support.

While some of the photographs visualise the extent to which the Swedish enterprise was Palestinian with Arab pupils and an Arab staff, the people in charge were always Swedish. This uneven relationship is seen in the photographs, with headmistress Signe Ekblad often in the background, as the matriarch in charge. Her presence underscores the colonial aspect of the Swedish humanitarian enterprise in Palestine. Even so, on a personal level, Ekblad's photographs, visualising her emotional investment in female education, were instrumental in finding necessary Swedish support for developing a school that prospered in Jerusalem's highly competitive market of mission schools.

\section{Bibliography}

Ariel, Yaakov and Ruth, Kark. "Messianism, Holiness, Charisma, and Community: The American-Swedish Colony in Jerusalem, 1881-1933." Church History 65, no. 4 (1996): $641-657$.

Awad, Nada. "Waiting for the Second Coming: The New Photographic Collection of the American Colony Archives." Jerusalem Quarterly 61 (2015): 101-112.

Björk, Gustaf. Sverige i Jerusalem och Betlehem. Svenska Jerusalemsföreningen 19oo1948. Uppsala: Svenska Jerusalemsföreningen, 2000.

Ekblad, Signe. Lyckliga Arbetsår i Jerusalem. Uppsala: J.A. Lindblad, 1949.

Fahlgren, Sune, Mia Gröndahl, and Kjell Jonasson, eds. A Swede in Jerusalem. Signe Ekblad and the Swedish School, 1922-1948. Bethlehem: Diyar Publishing and Swedish Jerusalem's Society, 2012.

Fleischmann, Ellen. "At Home in the World: Globalizing Domesticity through Home Economics in the Interwar Years." In Transnational and Historical Perspectives on Global Health, Welfare and Humanitarianism, edited by E. Fleischmann, S. Grypma, M. Marten, and I.M. Okkenhaug, 158-181. Kristiansand: Portal Academic, 2013.

Forsgren, Peter. "Globalization as "The White Man's Burden": Modernity and Colonialism in a Swedish Travelogue." Scandinavian Studies 91, nos. 1-2 ( 2019): 222-223. 
Gröndal, Mia. The Dream of Jerusalem. Lewis Larsson and the American Colony Photographers. Stockholm: Journal, 2005.

Häggman, Sofia. Hilma Granqvist. Antropolog med hjärtat i Palestina. Vasa; SFV, 2017.

Hedin, Sven. Till Jerusalem. Stockholm: Bonnier, 1917.

Höglund, Johan and Linda Andersson Burnett. "Introduction: Nordic Colonialism and Scandinavian Studies." Scandinavian Studies 91, nos. 1-2 (2019): 1-12.

Jacobson, Abigail. "American "Welfare Politics": American Involvement in Jerusalem During World War I." Israeli Studies 18, no. 1 (2013): 56-76.

Jalagin, Seija, Inger Marie Okkenhaug and Maria Småberg. "Introduction: Nordic Missions, gender and humanitarian practices: from evangelization to development." Scandinavian Journal of History 40, no. 3 (2015): 285-297.

Larsson, Edith. Dalafolket i Heligt Land. Stockholm: Natur och Kultur, 1957.

Larsson, Lena. "The Larsson Design Legacy: A Personal View." In Carl and Karin Larsson. Creators of the Swedish Style, edited by Michael Snodin and Elisabeth Stavenow-Hidemark, 220-229. Boston/New York/Toronto/London: Little, Brown and Company, 1998.

Lien, Sigrid. Lengselens bilder. Oslo: Scandinavian Academic Press, 2007.

Lindqvist, Märta. Palestinska dagar. Stockholm: Skoglund Bokförlag, 1931.

Murre-van den Berg, Heleen, "Our Jerusalem": Bertha Spafford Vester and Christianity in Palestine during the British Mandate. In Britain, Palestine and the Empire: The Mandate Years, edited by Rory Miller, 328-331. Farnham/Burlington: Ashgate, 2010. Nassar, Issam. "Early local photography in Jerusalem." History of Photography 27, no. 4 (2015): 320-332.

Okkenhaug, Inger Marie. "Scandinavian Missionaries in Palestine: The Swedish Jerusalem's Society, Medical Mission and Education in Jerusalem and Bethlehem, 1900-1948." In Tracing the Jerusalem Code: Christian Cultures in Scandinavia, vol. 3., edited by Anna Bohlin and Ragnhild J. Zorgati. Berlin: De Gruyter Verlag, 2021.

Okkenhaug, Inger Marie. "Att avresa till Jerusalem som lärarinna: Signe Ekblad, jorsalsfarer, lærer og misjonær." In Religiøse reiser. Mellom gamle spor og nye mål, edited by Siv Ellen Kraft and Ingvild S. Gilhus, 121-134. Oslo: Universitetsforlaget, 2007.

Okkenhaug, Inger Marie. "Setting the Table at the Swedish School in Jerusalem: Food Distribution and Transnational Humanitarianism in Mandatory Palestine." In Food and Foodways in the Middle East, edited by Nefissa Naguib, 121-127. Ramallah: Bir Zeit University and Lower Jordan Series, 2009.

Okkenhaug, Inger Marie. "Signe Ekblad and the Swedish School in Jerusalem, 19221948." Svensk Missionstidskrift 2 (2006): 147-162.

Othman, Enaya Hammad Negotiating Palestinian Womanhood. Encounters between Palestinian Women and American Missionaries, 1880s-1940s. Lanham/Boulder/New York/London: Lexington Books, 2016. 
Pelletier, Mary. "Jerusalem's religious pilgrims who built a photographic empire." The Middle East Eye 16 February 2017. https:/www.middleeasteye.net/features/ jerusalems-religious-pilgrims-who-built-photographic-empire.

Stavenow-Hidemark, Elisabeth. “Carl Larsson's images-mass publication, distribution and influence." In Carl and Karin Larsson. Creators of the Swedish Style, edited by Michael Snodin and Elisabeth Stavenow-Hidemark, 220-229. Boston/New York/ Toronto/London: Little, Brown and Company, 1998.

Vester, Bertha Spafford. Our Jerusalem. An American Family in the Holy City, 1881-1949. London: Evans Brothers Limited, 1951. 